\title{
ANALISIS PENGARUH PENDAPATAN DAN BEBAN TERHADAP PAJAK : LABA SEBELUM PAJAK SEBAGAI VARIABEL INTERVENING PADA PT. BANK BENGKULU
}

\author{
Wagini, Dara Andalas, Karona Cahya Susena \\ Program Studi Akuntansi Fakultas Ekonomi Universitas Dehasen Bengkulu \\ Wagini980@gmail.com
}

\begin{abstract}
ABSTRAK
Wagini, Dara Andalas, Karona Cahya Susena; Penelitian ini bertujuan untuk melihat pengaruh pendapatan dan beban terhadap pajak dengan laba sebelum pajak sebagai variabel intervening. Data yang digunakan dalam penelitian ini merupakan data sekunder berupa laporan keuangan periode tahun 20102017. Metode pengujian data menggunakan analisis regresi linear berganda dengan uji $t$, uji $F$, dan uji koefisien determinasi.

Hasil penelitian menunjukkan bahwa pendapatan secara langsung berpengaruh negative dan tidak signifikan terhadap pajak, dengan pengaruh total -1.400 dan tingkat signifikansi 5,7\%. Sedangkan secara tidak langsung, pendapatan memiliki pengaruh yang positif dan signifikan terhadap pajak melalui laba sebelum pajak sebagai variabel intervening, dengan pengaruh total 1.401 dan tingkat signifikansi $0,07 \%$. Beban secara langsung memiliki pengaruh yang positif dan signifikan terhadap pajak, dengan pengaruh total 1.064 dengan tingkat signifikansi 3,6\%. Sedangkan secara tidak langsung beban juga memiliki pengaruh yang positif dan signifikan terhadap pajak dengan laba sebelum pajak sebagai variabel intervening, dengan pengaruh total 1.401 dengan tingkat signifikansi $0,07 \%$. Hasil analisis dapat disimpulkan bahwa laba sebelum pajak tepat digunakan sebagai variabel intervening untuk melihat pengaruh antara pendapatan, beban terhadap laba sebelum pajak karena dapat memberikan kontribusi pengaruh sebesar 94\%.Artinya, pajak yang harus dibayarkan oleh PT. Bank Bengkulu dipengaruhi oleh tiga factor penting, yaitu pendapatan, beban dan laba sebelum pajak.
\end{abstract}

\section{ABSTRACT}

Wagini, Dara Andalas, Karona Cahya Susena; This study aims to look at the effect of income and burden on taxes with pre-tax profit as an intervening variable. The data used in this study is secondary data in the form of financial statements for the period 2010-2017. Data testing method uses multiple linear regression analysis with t test, $\mathrm{F}$ test, and test coefficient of determination.

The results showed that income directly had a negative and not significant effect on taxes, with a total effect of -1.400 and a significance level of 5.7\%. Whereas indirectly, income has a positive and significant effect on taxes through pre-tax profit as an intervening variable, with a total influence of 1,401 and a level of significance of $0.07 \%$. Direct expenses have a positive and significant effect on taxes, with a total influence of 1,064 with a significance level of 3.6\%. Whereas indirectly the burden also has a positive and significant effect on tax with pre-tax profit as an intervening variable, with a total influence of 1,401 with a significance level of $0.07 \%$. The results of the analysis can be concluded that profit before tax is rightly used as an intervening variable to see the effect of income, expense on pre-tax profit because it can contribute influence by $94 \%$. That is, the tax that must be paid by PT. Bank Bengkulu is influenced by three important factors, namely income, expenses and pre-tax profits.

Key Words: Income, Expenses, Taxes, Profit Before Tax, Intervening.

\section{LATAR BELAKANG}

Laporan keuangan dapat menyajikan informasi tentang kinerja keuangan perusahaan, informasi tersebut dapat di sampaikan melalui laporan keuangan secara umum, yaitu neraca, laporanlaba rugi, laporan perubahan modal, laporan arus kas, serta catatan atas laporan keuangan.Masing-masing laporan keuangan tersebut mempunyai fungsi tersendiri dan saling berhubungan dalam hal penyampaian informasi keuangan. Informasi mengenai pencapaian kinerja keuangan perusahaan dapat dilihat pada laporan laba rugi yang menyajikan pendapatan, beban, pajak, serta laba bersih suatu perusahaan dalam periode tertentu.

Tindakan manajemen laba tentu akan sangat berpengaruh dengan informasi-informasi yang disampaikan yang berhubungan dengan laba perusahaan. Namun dalam penelitian ini, tindakan manajemen laba tidak menjadi fokus utama.Tingkat pendapatan perusahaan yang tinggi artinya kinerja 
perusahaan dalam kondisi yang baik, perusahaan mampu memanfaatkan berbagai sumber daya yang dimiliki dalam aktivitasnya untuk mencapai laba yang besar. Begitupun dengan beban operasional perusahaan, beban merupakan segala unsur pengorbanan perusahaan untuk mendapatkan sesuatu. Tingginya beban perusahaan akan sangat mempengaruhi laba perusahaan, oleh karena itu prosesefisiensi harus menjadi perhatian bagi manajemen perusahaan. Disamping beban operasional yang harus dikeluarkan perusahaan dalam memenuhi kebutuhnnya, pajak pengahasilan merupakan unsur yang tidak dapat dipisahkan.

Pajak merupakan iuran wajib kepada negara yang terhutang oleh orang pribadi atau badan yang bersifat memaksa, serta masyarakat tidak mendapatkan imbalan secara langsung. Besarnya pajak yang dibebankan tergantung dari besarnya laba yang diperoleh oleh perusahaan. Tarif pengenaan pajak penghasilan ditetapkan oleh Direktorat Jendaral Pajak (DJP) sebagai pedoman untuk melakukan pemungutan pajak penghasilan baik perorangan atau badan usaha. Tarif pajak yang ditetapkan inilah yang menjadi dasar bagi manajemen perusahaan untuk melakukan tindakan manajemen laba guna menghindari pembayaran pajak yang tinggi.

Perkembangan Bank Bengkulu ini juga sejalan dengan tingkat laba yang diperoleh setiap tahunnya semaking meningkat. Besarnya laba tentu dimulai dengan besarnya tingkat pendapatan yang diperoleh. Semkin besarnya pendapatan tentu akan berpengaruh terhadap pajak yang harus dibayar oleh perusahaan. Oleh sebab itu, peneliti tertarik untuk melakukan penelitian pengaruh secara langsung ataupun tidak langsung pendapatan dan beban terhadap pajak dengan mengangkat judul "Pengaruh Pendapatan dan Beban Terhadap Pajak : Laba Sebelum Pajak Sebagai Variabel Intervening (Studi Kasus Pada PT. Bank Bengkulu)".

\section{LANDASAN TEORI}

\section{Laporan Keuangan}

Laporan keuangan adalah hasil dari proses akuntansi yang dapat digunakan sebagai alat untuk mengkomunikasikan data keuangan atau aktivitas perusahaan kepada pihak-pihak yang berkepentingan (Hery, 2016:3). Menurut Jumingan (2010:4) mendefinisikan laporan keuangan sebagai hasil pembuatan ringkasan data keuangan perusahaan yang disusun dan ditafsirkan untuk kepentingan manajemen dan pihak lain yang menaruh perhatian atau mempunyai kepentingan dengan data keuangan perusahaan.

Sedangkan Munawir (2011:51) mengatakan bahwa laporan keuangan merupakan alat yang sangat penting untuk memperoleh informasi sehubungan dengan posisi keuangan dan hasil-hasil yang telah dicapai perusahaan yang bersangkutan.Laporan keuangan menunjukkan kondisi keuangan secara keseluruhan, dari laporan keuangan ini akan terbaca bagaimana kondisi perusahaan yang sesungguhnya termasuk kelemahan dan kekuatan yang dimilikinya (Kasmir, 2014:281)

Menurut Hery (2016:5) tujuan laporan keuangan terdiri dari dua jenis organisi, yaitu organisasi yang bersifat profit oriented dan organisasi yang tidak bersifat profit oriented.

1. Tujuan laporan keuangan untuk organisasi yang bersifat profit oriented adalah :

a. Memberikan informasi yang berguna bagi investor, kreditor, dan pemakai lainnya dalam membuat keputusan secara rasional mengenai investasi, kredit, dan lainnya.

b. Memberikan informasi untuk membantu investor atau calon investor dan kredit serta pemakai lainnya dalam menentukan jumlah, waktu, dan prospek penerimaan kas dari dividen atau bungan dan juga penerimaan dari penjualan, piutang, atau saham, dan pinjaman yang jatuh tempo.

c. Memberikan informasi tentang sumber daya (aset) perusahaan, klaim atas aset, dan pengaruh transaksi, peristiwa, dan keadaan lain terhadap aset dan kewajiban.

d. Memberikan informasi tentang kinerj akeuangan perusahaan selama satu periode tertentu.

e. Memberikan informasi tentang bagaimana perusahaan mendapatkan dan membelanjakan kas, tentang pinjaman dan pengambaliannya, tentang transaksi yang mempengaruhi modal, termasuk dividend dan pembayaran lainnya kepada pemilik, dan tentang faktor-faktor yang mempengaruhi likuiditas dan solvabilitas perusahaan.

f. Memberikan informasi tentang bagaimana manajemen perusahaan mempertanggungjawabkan pengelolaan perusahaan kepada pemilik atas penggunaan sumber daya (aset) yang telah dipercayakan kepadanya.

g. Memberikan informasi yang berguna bagi manajemr dan direksi dalam proses pengambilan keputusan untuk kepentingan pemiliki perusahaan.

2. Tujuan laporan keuangan untuk organisasi yang tidak bersifat profit oriented adalah :

a. Sebagai dasar dalam pengambilan keputusan mengenai alokasi sumber daya (aset) perusahaan.

b. Untuk menilai kemampuan organisasi dalam memberikan pelayanan kepada publik.

c. Untuk menilai bagaimana manajemen melakukan aktivitas pembiayaan dan investasi. 
d. Memberikan informasi tentang sumber daya (aset), kewajiban, dan kekayaan bersih perusahaan, serta perubahannya.

e. Memberikan informasi tentang kinerja organisasi.

f. Memberikan informasi tentang kemampuan organisasi dalam melunasi kewajiban jangka pendeknya.

\section{Karakteristik Kualitatif Informasi Keuangan}

Menurut Fahmi (2015:8) karateristik kualitatif informasi keuangan tersebut adalah :

1. Dapat dipahami

Suatu informasi keuangan dapat bermanfaat apabila dapat dipahami oleh para penggunya. Pengguna laporan keuangan merupakan pihak-pihak yang berasal dari berbagai macam kalangan dengan latar belakang pendidikan yang berbeda-beda. Laporan keuangan harus disajikan dengan bahasa yang sederhana, singkat, formal, dan mudah dipahami.

2. Relevan

Informasi keuangan yang relevan harus memiliki nilai prediktif sehinggan relevan digunakan dalam melakukan prediksi keuangan. Suatu informasi dikatakan relevan apabila disajikan dengan memperhatikan prinsip materialitas. Informasi yang ada pada laporan keuangan harus relevan dengan pengambilan keputusan, sebab jika tidak relevan dengan pengambilan keputusan maka laporan keuangan tidak akan memberikan manfaat bagi para penggunanya dalam melakukan evaluasi keuangan perusahaan.

3. Andal atau dapat dipercaya

Informasi yang ada pada laporan keuangan akan sangat bermanfaat apabila disajikan dengan andal atau dapat dipercaya. Laporan keuangan dapat dipercaya apabila disajikan secara jujur. Disamping itu, laporan keuangan harus disajikan dengan prinsip substance over form atau penyajian yang lebih mengutamakan hakikat ekonomi ketimbang hakikat formal. Laporan keuangan juga harus disajikan dengan prinsip kehati-hatian atau konservatif dan lengkap.

4. Dapat dibandingkan

Informasi keuangan harus memiliki sifat daya banding. Untuk mencapai kualitas tersebut, laporan keuangan harus disajikan secara komparatif dengan tahun-tahun sebelumnya. Laporan keuangan yang disajikan secara komparatif sangat bermanfaat karena memiliki daya banding, laporan keuangan juga harus menggunakan teknik-teknik dan basis-basis pengukuran yang konsisten.

\section{Laporan Laba Rugi}

Laporan laba rugi merupakan laporan yang menyajikan hasil usaha perusahaan selama periode tertentu, pos-pos yang ditampilkan dalam laporan ini berupa pendapatan dan beban, sehingga dapat menggambarkan kondisi perusahaan mengalami untung atau rugi(Fahmi, 2015:4):

1. Pendapatan

Menurut Hery (2013:46) pendapatan adalah arus masuk dari aktiva atau peningkatan yang lain dari aktiva atau penyelesaian suatu kewajiban entitas atau kombinasi dari keduanya mulai dari pengirim barang, pemberian jasa, atau aktiva lainnya yang merupakan kegiatan operasi utama dari perusahaan.

Sedangkan menurut Stice, dkk (2009:516) menyatakan pendapatan adalah arus masuk atau peningkatan lain dari suatu aset suatu entitas atau pelunasan utang-utangnya atau kombinasi dari keduanya) yang dihasilkan dari penyerahan atau produksi barang, pemberian jasa, atau aktivitasaktivitas lainnya yang merupakan operasi utama atau operasi sentran yang berkelanjutan dari entitas tersebut.

2. Beban

Beban secara umum dapat diartikan sebagai segala pengeluaran yang ditanggung oleh perusahaan atas kegiatan operasional perusahaan. Manajemen perusahaan harus mampu menjaga tingkat efisiensi agar tidak terjadi beban yang besar yang akan dapat mengurani laba perusahaan. Hery (2017:123) menyatakan bahwa beban adalah arus keluar aktiva atau penggunaan lainnya atas aktiva atau terjadinya (munculnya) kewajiban entitas (atau kombinasi dari keduanya) yang disebabkan oleh pengirim atau pembuat barang, pemberi jasa, atau aktivitas lainnya yang merupakan operasi utama atau operasi sentral perusahaan.

Beban menurut Darminto (2014:12) adalah sebagai penurunan manfaat ekonomi selama periode akuntansi dalam bentuk arus kas keluar atau berkurangnya aktiva atau terjadinya kewajiban yang mengakibatkan penurunan ekuitas yang tidak menyangkut pembagian kepada penanam modal.

3. Laba Sebelum Pajak

Menurut Kasmir (2014:56) laba sebelum pajak merupakan laba hasil operasi perusahaan selama satu periode sebelum dikurangi oleh beban pajak pengahsilan yang harus ditanggung oleh perusahaan. 
Laba merupakan salah satu indikator yang dapat digunakan untuk mengukur kinerja manajemen perusahaan dalam menjalankan bisnisnya. Besarnya perolehan laba dalam satu periode ke periode menunjukkan naik turunnya kinerja manajemen perusahaan. Laba sebelum pajak merupakan laba bersih sebelum dikurangi pajak penghasilan (Hery, 2017:42)

4. Pajak

Menurut Andriani dalam Susena dan Asriyani (2016:137) pajak adalah iuran kepada negara (yang dapat dipakasakan) yang terutang oleh yang wajib membayarnya menurut peraturan-peraturan, dengan tidak mendapat prestasi-kembali, yang langsung dapat ditunjuk, dan yang gunanya adalah untuk membiayai pengeluaran-pengeluaran umum terkait dengan tugas negara untuk menyelenggarakan pemerintah. Sedangkan menurut Resmi (2015:74) pajak penghasilan merupakan pajak yang dikenakan terhadap orang pribadi dan badan, berkenaan dengan penghasilan yang diterima atau diperoleh selama satu tahun pajak.

Pembayaran pajak penghasilan atas keuntungan atau laba yang diperoleh akan berdampak terhadap penurunan laba bersih. Oleh karena itu, kerap kali manajemen perusahaan melakukan earning manajemen atau manajemen laba. Rekayasa laba ini dilakukan manajemen atau penyusun laporan keuangan, karena mereka mengharapkan suatu manfaat dari tindakan yang dilakukan salah satunya nya yaitu untuk mengurangi beban pajak.

Tindakan manajemen laba tidak selalu tentang memanipulasi data atau informasi akuntansi, tetapi cenderung dikaitkan dengan pemilihan metode akuntansi yang diperkenankan menurut standar akuntansi. Tindakan manajemen laba dilakukan dengan operating manipulation dan accounting manipulation, manipulasi operasi berkaitan dengan usaha untuk merubah keputusan operasional yang dapat mempengaruhi aliran dana dan pendapatan bersih. Sedangkan manipulasi akuntansi berkaitan dengan penggunaan fleksibilitas dalam metode akuntansi untuk merubah besarnya laba. Tindakan manajemen laba dari sisi operasi akan dapat mempengaruhi nilai pendapatan dan beban yang ditampilkan dalam laporan keuangan untuk melakukan pengurangan terhadap beban pajak,

Hubungan antara pajak penghasilan dengan tindakan manajemen laba merupakan hubungan yang tidak dapat dipisahkan dalam dunia bisnis. Karena tindakan manajemen laba akan mempengaruhi nilai pendapatan dan beban yang ditampilkan dalam laporan keuangan. Pajak penghasilan merupakan salah satu element yang sangat mempengaruhi nilai laba bersih perusahaan, oleh karena itu sering sekali perusahaan untuk melakukan penghindaran pajak dengan cara melakukan tindakan manajemen laba.

5. Laba Bersih Setelah Pajak

Laba merupakan suatu ukuran kinerja perusahaan, laba kerap kali dipandang sebagai keberhasilan atau kegagalan manajemen perusahaan dalam melaksanakan kegiatan operasional perusahaan dalam satu periode. Laba merupakan salah satu informasi yang faktual untuk menilai kemampuan perusahaan. Laba secara umum digambarkan sebagai selisih antara pendapatan dengan beban yang dikeluarkan untuk menghasilkan pendapatan. Oleh karena itu, pengukuran pendapatan sering kali dihubungkan dengan pengukuran laba. Menurut Yusuf (2011:31) laba merupakan selisih lebih antara pendapatan dengan beban atau rugi adalah selisih kurang antara pendapatan dengan beban sehingga laba merupakan selisih lebih atau kurang antara pendapatan dengan beban. Sedangkan menurut Hery (2017:123) laba atau keuntungan merupakan kenaikan dalam ekuitas (aktiva bersih) entitas yang ditimbulkan oleh transaksi peripheral (transaksi di luar operasi utama atau operasi sentral perusahaan) atau transaksi insendentil (transaksi yang terjadinya jarang) dan dari seluruh transaksi lainnya serta peristiwa maupun keadaan-keadaan lainnya yang mempengaruhi entitas, tidak termasuk yang berasal dari pendapatan atau investasi oleh pemilik.

Menurut Herry (2017:134) menjelaskan bahwa laba entitas memiliki beberapa jenis, yaitu:

1. Laba kotor

Laba kotor merupakan laba yang diperoleh dari penjualan atau pendapatan bersih yang dikurangi dengan harga pokok penjualan. Disebut laba kotor karena belum memperhitungkan beban operasional yang dikeluarkan untuk mendapatkan pendapatan dalam satu periode.

2. Laba operasional

Laba operasional mengukur kinerja fundamental operasi perusahaan dan dihitung sebegai selisih antara laba kotor dengan beban operasional.

3. Laba dari operasi berlanjut sebelum pajak penghasilan

Laba dari operasi berlanjut sebelum pajak penghasilan merupakan laba operasional ditambah dengan pendapatan dan keuntungan lain-lain dan dikurangkan dengan beban dan kerugian lainlain

4. Laba dari operasi berlanjut 
Laba dari operasi berlanjut merupakan selisih antara laba sebelum pajak dengan laba setelah dikurangi pajak pengahasilan. Laba dari operasi berlanjut dapat menggambarkan aspek kinerja atau ukuran keberhasilan manajemen dalam mengelolah perusahaan secara keseluruhan.

5. Laba bersih

Laba bersih akan sama besarnya dengan laba operasi berlanjut apabila tidak ada pos-pos biasa (irregular item), yaitu operasi yang dihentikan (discontginued item) dan pos luar biasa (extraordinary items).

6. Laba per saham

Laba per saham merupakan bersarnya laba bersih atas setiap lembar saham biasa yang beredar.

\section{KERANGKA ANALISIS}

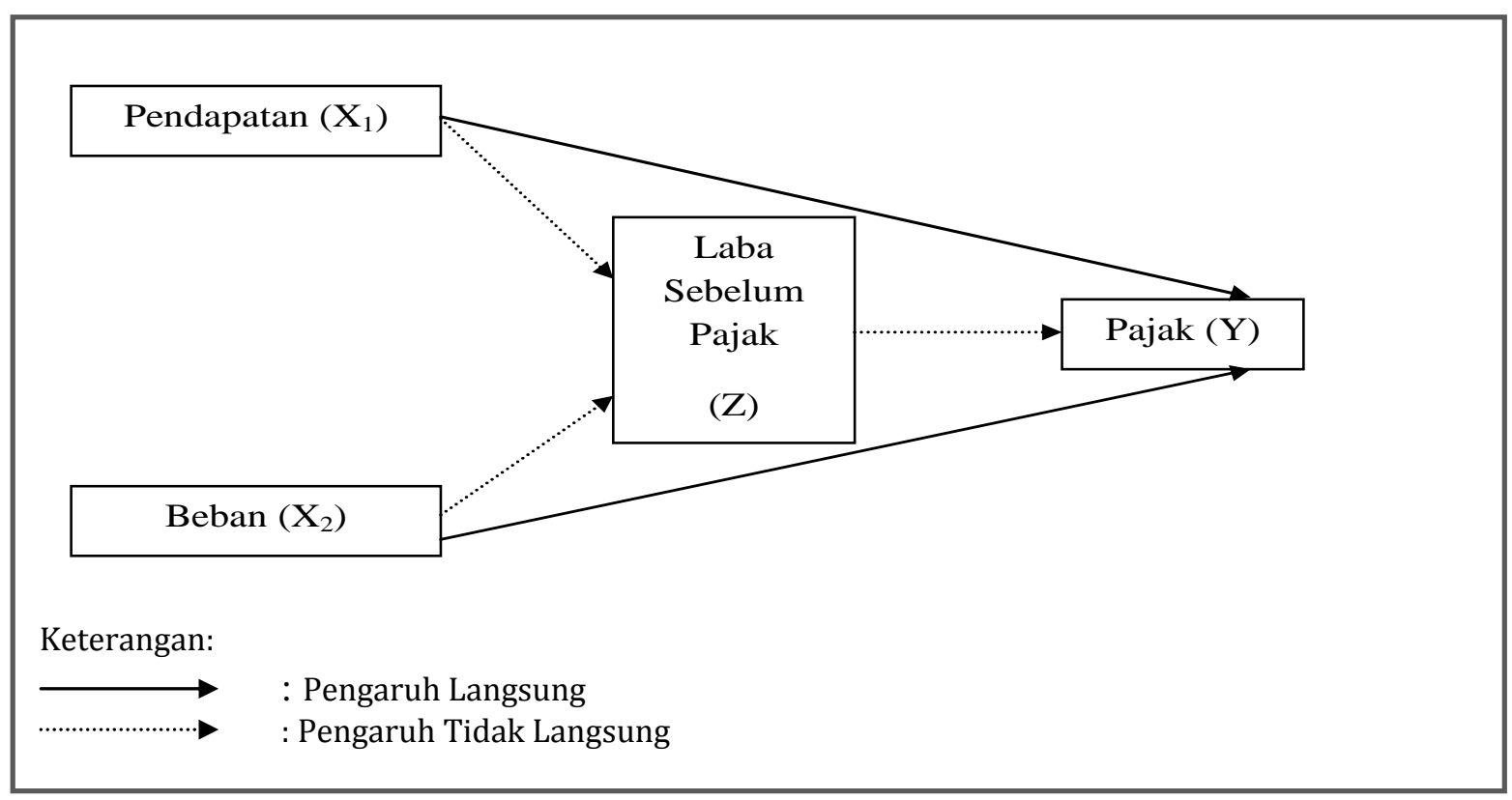

Gambar 1. Kerangka Analisis

\section{METODOLOGI}

\section{Jenis dan Metode Pengumpulan Data}

Jenis penelitian ini merupakan penelitian kuantitatif yang menggunakan data sekunder berupa laporan keuangan PT. Bank Bengkulu periode tahun 2010 sampai 2017. Penelitian kuantitatif adalah suatu proses menemukan pengetahuan yang menggunakan data berupa angka sebagai alat menganalisis keterangan mengenai apa yang ingin diketahui (Kasiram, 2008:149). Data sekunder adalah informasi tangan kedua yang telah dikumpulkan oleh beberapa orang (organisasi) untuk tujuan tertentu dan tersedia untuk berbagai penelitian (Riadi, 2016:48).

Variabel independen dalam penelitian ini adalah pendapatan $\left(\mathrm{X}_{1}\right)$ dan Beban $\left(\mathrm{X}_{2}\right)$, sedangkan variabel dependen nya adalah pajak (Y) serta yang berperan sebagai variabel mediasi atau variabel intervening adalah laba sebelum pajak (Z). Wijaya (2011:5) menyatakan variabel independen merupakan variabel yang fungsinya menerangkan (mempengaruhi) variabel dependen. Sedangkan variabel dependen merupakan variabel yang dipengaruhi. Serta menyebutkan variabel mediasi sebagai variabel yang mempengaruhi hubungan variabel yang sedang diteliti.

Metode pengumpulaan data dalam penelitian ini dengan cara observasi tidak langsung dan studi kepustakawan. Observasi tidak langsung yaitu pengumpulan data laporan keuangan melalui sumber yang telah tersedia berupa website PT. Bank Bengkulu dan dapat di akses melalui www.bankbengkulu.co.id, laporan keuangan yang digunakan dalam penelitian ini berupa laporan laba rugi PT. Bank Bengkulu.Serta studi kepustakawan dilakukan guna memperoleh landasan teori dan konsep yang kuat agar dapat memecahkan permasalahan, maka peneliti melakukan penelitian kepustakawan dengan membaca melalui literatur-literatur berupa text book dan sumber-sumber lain yang berhubungan dengan topik yang dibahas. 


\section{Metode Analisis}

Analisis data dalam penelitian ini menggunakan asumsi klasik dan analisis regresi bertahapdengan software statistic versi 17.Analisis bertahap digunakan untuk menguji pendapatan dan beban terhadap laba sebelum pajak atau uji yang dilakukan untuk melihat pengaruh secara tidak langsung antara variabel independen terhadap variabel dependen yang di mediasi oleh laba sebelum pajak. Serta menguji pengaruh pendapatan dan beban terhadap pajak atau uji secara langsung untuk melihat pengaruh antara variabel independen terhadap variabel dependen tanpa variabel mediasi laba sebelum pajak

\section{Analisis Regresi}

Analisis regresi digunakan untuk melihat pengaruh lebih dari satu variabel independen terhadap variabel dependen. Analisis regresi untuk melihat pengaruh variabel independen terhadap variabel dependen yang dimediasi oleh variabel intervening laba sebelum pajak dilakukan dengan dua tahap (Wijaya, 2011:142).

Uji regresi tahap pertama dilakukan untuk melihat pengaruh tidak langsung antara variabel independen Pendapatan $\left(\mathrm{X}_{1}\right)$ dan Beban $\left(\mathrm{X}_{2}\right)$ terhadap variabel dependen Pajak $(\mathrm{Y})$ yang dimediasi variabel intervening Laba Sebelum Pajak (Z). Uji regresi tahap kedua dilakukan untuk melihat pengaruh secara langsung variabel independen Pendapatan $\left(\mathrm{X}_{1}\right)$ dan Beban $\left(\mathrm{X}_{2}\right)$ terhadap Pajak (Y).Suatu variabel dikatakan sebagai variabel intervening jika pengaruh tidak langsung lebih besar dari pengaruh langsung, tingkat signifikansi yang digunakan dalam penelitian ini adalah sebesar $0.05 \%$ atau 5\%. Jika tingkat signifikan sebesar 5\%, maka terdapat pengaruh antara variabel independenden terhadap variabel dependen, serta sebaliknya jika tingkat signifikansi lebih besar dari $0.05 \%$ berarti tidak terdapat pengaruh antara variabel independen terhadap variabel dependen (Wijaya, 2011:149).

Persamaan uji regresi dua tahap adalah sebagai berikut.

\section{Uji regresi tahap pertama :}

Intervening Variabel $=$ Independen Variabel

$\mathrm{Z}=\mathrm{a}+\mathrm{b}_{1} \mathrm{X}_{1}+\mathrm{b}_{2} \mathrm{X}_{2}$

Uji regresi tahap kedua :

Dependen variabel $=$ Independen variabel + Intervening Variabel

$\mathrm{Y}=\mathrm{a}+\mathrm{b}_{1} \mathrm{X}_{1}+\mathrm{b}_{2} \mathrm{X}_{2}+\mathrm{b}_{3} \mathrm{Z}$

Keterangan :

$\mathrm{b}_{1} \mathrm{X}_{1}$

$\mathrm{b}_{2} \mathrm{X}_{2}$

$\mathrm{b}_{3} \mathrm{Z}$

Y

= Variabel Intervening

= Konstanta

= Koefisien Varibel Pendapatan

= Koefisien Variabel Beban

= Koefisien Variabel Intervening

$=$ Pajak

\section{HASIL PENELITIAN DAN PEMBAHASAN}

Sumber data yang digunakan merupakan laporan laba rugi PT. Bank Bengkulu periode tahun 2010 sampai 2017. Berikut data pendapatan, beban, laba sebelum pajak, dan pajak PT. Bank Bengkulu.

Tabel 1. Pendapatan, Beban, Laba Sebelum Pajak, dan Pajak

\begin{tabular}{|r|r|r|r|r|}
\hline Tahun & Pendapatan & \multicolumn{1}{|c|}{ Beban } & Laba Sebelum Pajak & \multicolumn{1}{c|}{ Pajak } \\
\hline 2010 & 323.719 .426 .009 & 231.988 .600 .257 & 91.730 .825 .749 & 26.006 .786 .313 \\
\hline 2011 & 293.575 .847 .605 & 376.578 .608 .532 & 71.450 .095 .729 & 30.058 .229 .637 \\
\hline 2012 & 355.743 .800 .000 & 253.849 .557 .000 & 101.894 .243 .000 & 32.093 .130 .000 \\
\hline 2013 & 455.119 .193 .000 & 312.376 .602 .000 & 142.509 .992 .000 & 39.250 .304 .000 \\
\hline 2014 & 518.980 .439 .000 & 373.950 .544 .000 & 145.029 .849 .000 & 38.854 .904 .000 \\
\hline 2015 & 675.496 .841 .000 & 505.883 .321 .000 & 151.613 .520 .000 & 39.453 .175 .000 \\
\hline 2016 & 687.522 .230 .000 & 532.052 .757 .000 & 155.469 .473 .000 & 42.337 .658 .000 \\
\hline 2017 & 735.078 .294 .000 & 596.562 .514 .000 & 138.515 .780 .000 & 38.380 .465 .000 \\
\hline Total & 4.045 .236 .070 .614 & 3.183 .242 .503 .789 & 998.213 .778 .478 & 286.434 .651 .950 \\
\hline
\end{tabular}

Sumber : Laporan Keuangan, Data Diolah, 2019. 


\section{Hasil Uji Regresi Pertama}

Hasil uji regresi tahap pertama digunakan untuk melihat pengaruh antara variabel independen terhadap variabel intervening, yaitu Pendapatan $\left(\mathrm{X}_{1}\right)$, Beban $\left(\mathrm{X}_{2}\right)$ terhadap Laba Sebelum Pajak $(\mathrm{Z})$. Hasil pengujian regresi tahap pertama adalah sebagai berikut :

\section{Tabel 2. Koefisien Determinasi Pendapatan $\left(\mathrm{X}_{1}\right)$, Beban $\left(\mathrm{X}_{2}\right)$ Terhadap Laba Sebelum Pajak $(\mathrm{Z})$} Model Summary

\begin{tabular}{|c|r|r|r|c|}
\hline $\begin{array}{l}\text { Mode } \\
\mathrm{l}\end{array}$ & $\mathrm{R}$ & R Square & \multicolumn{1}{c|}{$\begin{array}{c}\text { Adjusted R } \\
\text { Square }\end{array}$} & $\begin{array}{c}\text { Std. Error of the } \\
\text { Estimate }\end{array}$ \\
\hline 1 & $.940^{\mathrm{a}}$ & .883 & .836 & 1.28310 \\
\hline
\end{tabular}

a. Predictors: (Constant), Beban (X2), Pendapatan (X1)

Sumber : Output Statistic Versi 17, Data Diolah, 2019.

Tabel di atas menjelaskan bahwa angka $R$ Square sebesar 0,883 yang merupakan pengkuadratan dari koefisien korelasi, yaitu $0,940 \times 0,940 . R$ Square bisa disebut koefisien determinasi, yang dalam hal ini berarti 0,883 atau $88,3 \%$ laba sebelum pajak dapat dijelaskan oleh variabel pendapatan dan beban. Sedangkan sisanya $(100 \%-88,3 \%=11,7 \%)$ dijelaskan oleh variabel di luar penelitan. Karena nilai $R$ Square tersebut di atas 0,05 atau 5\%, maka pengaruh antara variabel independen terhadap variabel intervening sangat kuat. Nilai $R$ Square yang besar menunjukkan bahwa kemampuan variabel independen dalam menjelaskan pengaruh nya terhadap variabel intervening sangat luas.

Tabel 3. Uji Signifikansi Simultan

ANOVA $^{\mathrm{b}}$

\begin{tabular}{|ll|r|r|r|r|r|}
\hline Model & & Sum of Squares & df & Mean Square & F & Sig. \\
\hline 1 & Regression & $6.212 \mathrm{E} 21$ & 2 & $3.106 \mathrm{E} 21$ & 18.858 & $.005^{\mathrm{a}}$ \\
& Residual & $8.235 \mathrm{E} 20$ & 5 & $1.647 \mathrm{E} 20$ & & \\
& Total & $7.035 \mathrm{E} 21$ & 7 & & & \\
\hline
\end{tabular}

a. Predictors: (Constant), Beban (X2), Pendapatan (X1)

b. Dependent Variable: Laba Sebelum Pajak (Z)

Sumber: Output Statistic Versi 17, Data Diolah, 2019

Hasil uji signifikansi simultan atau uji ANOVA, menyatakan bahwa variabel independen Pendapatan $\left(\mathrm{X}_{1}\right)$, Beban $\left(\mathrm{X}_{2}\right)$ secara simultan berpengaruh positif dan signifikan terhadap Laba Sebelum Pajak (Z) dengan nilai Fhitung sebesar 18.858 dan tingkat signfikansi sebsar 0,005.

\section{Tabel 4. Uji Signifikansi Individual} Coefficients ${ }^{a}$

\begin{tabular}{|c|c|c|c|c|c|c|}
\hline & \multirow[t]{2}{*}{ Model } & \multicolumn{2}{|c|}{$\begin{array}{l}\text { Unstandardized } \\
\text { Coefficients }\end{array}$} & \multirow{2}{*}{$\begin{array}{c}\begin{array}{c}\text { Standardized } \\
\text { Coefficients }\end{array} \\
\text { Beta }\end{array}$} & \multirow[t]{2}{*}{$\mathrm{t}$} & \multirow[t]{2}{*}{ Sig. } \\
\hline & & B & Std. Error & & & \\
\hline \multirow[t]{3}{*}{1} & (Constant) & $5.838 \mathrm{E} 10$ & $1.526 \mathrm{E} 10$ & & 3.826 & .012 \\
\hline & Pendapatan (X1) & .297 & .062 & 1.655 & 4.760 & .005 \\
\hline & Beban (X2) & -.211 & .082 & -.893 & -2.567 & .050 \\
\hline
\end{tabular}

a. Dependent Variable: Laba Sebelum Pajak (Z)

Dari tabel di atas, pendapatan berpengaruh positif dan signifikan terhadap laba sebelum pajak dengan tingkat signifikansi sebesar 0,005 atau 0,5\% dengan thitung sebesar 4,760. Sedangkan beban berpengaruh negatif dan signifikan terhadap laba sebelum pajak dengan tingkat signifansi sebesar dan 0.050 atau $5 \%$ dengan $t_{\text {hitung }}-2.567$. Persamaan regresi pada uji tahap pertama yaitu $Z=5.838+0,297 \mathrm{X}_{1}$ - 0,211 $X_{2}$. Artinya, persamaan tersebut menyatakan jika $X_{1}$ dan $X_{2}$ adalah 0 , maka variabel $Z$ akan konstan sebesar 5.838. Apabila terjadi kenaikan $\mathrm{X}_{1}$ sebesar 1 dan $\mathrm{X}_{2}$ konstan, maka akan terjadi peningkatan $\mathrm{Z}$ sebesar 0.297 . Apabila terjadi penurunan $\mathrm{X}_{2}$ sebesar 1 dan $\mathrm{X}_{1}$ konstan, maka terjadi penurunan Z sebesar 0.211 . 


\section{Hasil Uji Regresi Kedua}

Uji regresi tahap kedua digunakan untuk melihat pengaruh variabel independen terhadap variabel dependen dengan melalui laba sebelum pajak sebagai variabel intervening. Hasil uji regresi tahap kedua adalah sebagai berikut :

Tabel 5. Koefisien Determinasi Pendapatan $\left(X_{1}\right)$, Beban $\left(X_{2}\right)$, dan Laba Sebelum Pajak $(Z)$ Terhadap Pajak (Y)

\begin{tabular}{|c|c|r|r|c|}
\hline Model & \multicolumn{1}{|c|}{ Model Summary } \\
\hline 1 & $.980^{\mathrm{a}}$ & \multicolumn{1}{|c|}{ R Square } & $\begin{array}{c}\text { Adjusted R } \\
\text { Square }\end{array}$ & $\begin{array}{c}\text { Std. Error of the } \\
\text { Estimate }\end{array}$ \\
\hline
\end{tabular}

a. Predictors: (Constant), Laba Sebelum Pajak (Z), Beban (X2),

Pendapatan (X1)

Sumber: Output Statistic Versi 17, Data Diolah, 2019

Tabel di atas menjelaskan bahwa angka $R$ Square sebesar 0,961 yang merupakan pengkuadratan dari koefisien korelasi, yaitu $0,980 \times 0,980 . R$ Square bisa disebut koefisien determinasi, yang dalam hal ini berarti 0,961 atau $96,1 \%$ pajak dapat dijelaskan oleh variabel pendapatan dan beban melalui laba sebelum pajak sebagai intervening. Sedangkan sisanya $(100 \%-96,1 \%=3,9 \%)$ dijelaskan oleh variabel di luar penelitan. Karena nilai $R$ Square tersebut di atas 0,05 atau $5 \%$, maka pengaruh antara variabel independen terhadap variabel dependen melalui variabel intervening sangat kuat. Nilai $R$ Square yang besar menunjukkan bahwa kemampuan variabel independen dalam menjelaskan pengaruhnya terhadap variabel dependen melalui variabel intervening sangat kuat.

\section{Tabel 6. Uji Signifikansi Simultan}

ANOVA $^{b}$

\begin{tabular}{|ll|r|r|r|r|r|}
\hline Model & Sum of Squares & df & Mean Square & F & Sig. \\
\hline 1 & Regression & $2.178 \mathrm{E} 20$ & 3 & $7.259 \mathrm{E} 19$ & 32.845 & $.003^{\mathrm{a}}$ \\
& Residual & $8.840 \mathrm{E} 18$ & 4 & $2.210 \mathrm{E} 18$ & & \\
& Total & $2.266 \mathrm{E} 20$ & 7 & & & \\
\hline
\end{tabular}

a. Predictors: (Constant), Laba Sebelum Pajak (Z), Beban (X2), Pendapatan (X1)

b. Dependent Variable: Pajak (Y)

Sumber : Output Statistic Versi 17, Data Diolah, 2019

Hasil uji signifikansi simultan atau uji ANOVA, menyatakan bahwa variabel independen Pendapatan $\left(\mathrm{X}_{1}\right)$, Beban $\left(\mathrm{X}_{2}\right)$, dan variabel intervening Laba Sebelum Pajak (Z) secara simultan berpengaruh positif dan signifikan terhadap Pajak $(\mathrm{Y})$ dengan nilai $\mathrm{F}_{\text {hitung }}$ sebesar 32.845 dan tingkat signfikansi sebsar 0,003. Artinya, variabel independen dan variabel intervening dapat menjelaskan pengaruh nya secara luas terhadap variabel dependen. Hal ini juga menyatakan bahwa variabel laba sebelum pajak tepat digunakan sebagai variabel intervening karena dapat memberikan pengaruh yang lebih besar terhadap hasil pengujian.

Tabel 7. Uji Signifikansi Individual Coefficients $^{\mathbf{a}}$

\begin{tabular}{|l|r|r|r|r|r|}
\hline \multirow{2}{*}{ Model } & \multicolumn{2}{|c|}{$\begin{array}{c}\text { Unstandardized } \\
\text { Coefficients }\end{array}$} & \multicolumn{1}{c|}{$\begin{array}{c}\text { Standardized } \\
\text { Coefficients }\end{array}$} & \multirow{2}{*}{$\mathrm{t}$} & \multirow{2}{*}{ Sig. } \\
\cline { 2 - 4 } & \multicolumn{1}{|c|}{$\mathrm{B}$} & \multicolumn{1}{c|}{ Std. Error } & \multicolumn{1}{c|}{ Beta } & & \\
\hline 1 (Constant) & $7.262 \mathrm{E} 9$ & $3.503 \mathrm{E} 9$ & & 2.073 & .107 \\
& -.045 & .017 & -1.400 & -2.652 & .057 \\
Pendapatan (X1) & .045 & .015 & 1.064 & 3.115 & .036 \\
Beban (X2) & .268 & .052 & 1.491 & 5.166 & .007 \\
\hline
\end{tabular}

a. Dependent Variable: Pajak (Y)

Sumber: Output Statistic Versi 17, Data Diolah, 2019. 
Hasil pengujian secara individual memperoleh persamaan $Y=7,262-0,045 X_{1}+0,045 X_{2}+0,268$

Z. Yang menyatakan bahwa :

1. Jika Pendapatan $\left(\mathrm{X}_{1}\right)$, Beban $\left(\mathrm{X}_{2}\right)$, dan Laba Sebelum Pajak(Z)adalah Rp. 0, maka variabel Pajak (Y) akan konstan sebesar Rp. 7,262

2. Jika terjadi penurunan Pendapatan $\left(\mathrm{X}_{1}\right)$ sebesar Rp. 1 sedangkan Beban $\left(\mathrm{X}_{2}\right)$, dan Laba Sebelum Pajak(Z) konstan, maka akan terjadi penurunan Pajak (Y) sebesar Rp. 0,045.

3. Jika terjadi peningkatan Beban $\left(\mathrm{X}_{2}\right)$ sebesar Rp. 1 sedangkan Pendapatan $\left(\mathrm{X}_{1}\right)$, dan Laba Sebelum Pajak(Z) konstan, maka akan terjadi peningkatan Pajak (Y) sebesar Rp. 0,045.

4. Jika terjadi peningkatan laba sebelum pajak (Z) sebesar Rp. 1 sedangkan Pendapatan (X1), Beban (X2) konstan maka akan terjadi peningkatan Pajak (Y) sebesar Rp. 0,268

Berdasarkan hasil pengujian regresi tahap pertama dan tahap kedua, maka dapat digambarkan pengaruh variabel Pendapatan $\left(\mathrm{X}_{1}\right)$, Beban $\left(\mathrm{X}_{2}\right)$, Laba Sebelum Pajak $(\mathrm{Z})$ terhadap Pajak $(\mathrm{Y})$ adalah sebagai berikut :

Gambar 2. Kesimpulan Hasil Uji Regresi

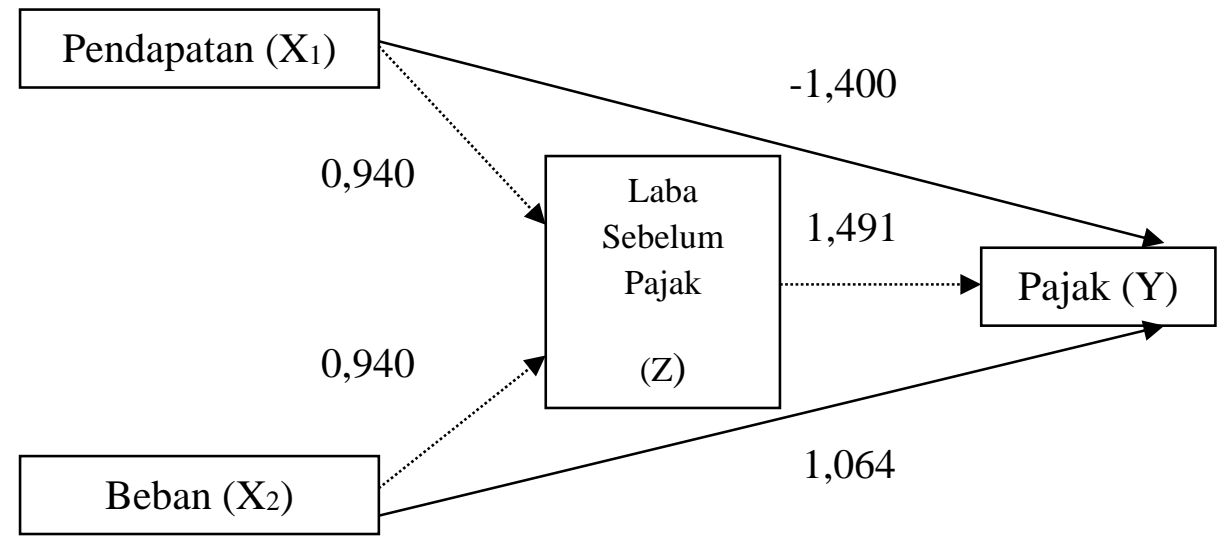

a. Pengaruh Total Pendapatan $\left(\mathrm{X}_{1}\right)$ ke Pajak $(\mathrm{Y})$ melalui

Laba Sebelum Pajak (Z)

- Pengaruh Tidak Langsung

- Pengaruh Langsung

Pengaruh Total

$0,940 \times 1,491=1.401$

$=-1.400+$

$=2.801$

b. Pengaruh Total Beban ( $\left.\mathrm{X}_{1}\right)$ ke Pajak $(\mathrm{Y})$ melalui Laba

Sebelum Pajak (Z)

- Pengaruh Tidak Langsung

- Pengaruh Langsung

Pengaruh Total

$0,940 \times 1,491=1.401$

$=1,064+$

$=2.465$

Berdasarkan perhitungan di atas, dapat disimpulkan bahwa pengaruh tidak langsung variabel pendapatan dan beban lebih besar dari pada pengaruh langsung melalui laba sebelum pajak sebagai variabel intervening. Jadi, dapat disimpulkan bahwa laba sebelum sebelum pajak tepat digunakan sebagai variabel intervening.

Hasil analisis pada gambar 2 di atas menjelaskan bahwa variabel Pendapatan $\left(\mathrm{X}_{1}\right)$ memiliki pengaruh langsung terhadap variabel laba sebelum pajak (Z) sebesar 0,940 atau $94 \%$. Pendapatan memiliki pengaruh tidak langsungnya terhadap pajak melalui laba sebelum pajak adalah sebesar 1,491. Sedangkan pengaruh langsung antara pendapatan dan pajak adalah sebesar -1.400 , secara total pengaruh pendapatan terhadap pajak melalui laba sebelum pajak sebagai variabel intervening adalah sebesar 2.801. Hasil analisis tersebut menunjukkan bahwa pengaruh tidak langsung lebih besar dari pengaruh langsung, maka dapat disimpulkan bahwa laba sebelum pajak tepat digunakan sebagai variabel intervening antara pendapatan terhadap pajak.

Beban memiliki pengaruh terhadap variabel intervening laba sebelum pajak sebesar 0,940 atau 94\%. Beban juga memiliki pengaruh tidak langsung terhadap pajak melalui laba sebelum pajak sebagai variabel intervening dengan besaran pengaruh sebesar 1,491. Sedangkan pengaruh langsung antara beban dan pajak adalah sebesar 1,064, secara total pengaruh beban terhadap pajak melalui laba sebelum pajak sebagai variabel intervening adalah sebesar 2.465. Hasil analisis pengaruh beban terhadap pajak menunjukkan pengaruh tidak langsung lebih besar dari pengaruh langsung, maka dapat dikatakan bahwa 
variabel laba sebelum pajak tepat digunakan sebagai variabel intervening. Variabel laba sebelum pajak sebagai variabel intervening antara pendapatan, beban terhadap pajak dapat memberikan pengaruh sebesar 94\%. Artinya, besaran pajak yang harus dibayarkan oleh PT. Bank Bengkulu dipengaruhi oleh ketiga faktor tersebut, yaitu : pendapatan, beban, dan laba sebelum pajak

Berdasarkan teori-teori dan hasi analisis diatas maka di jelaskan bahwa:

1. Uji Regresi Tahap Pertama

Dalam pengujian regresi tahap pertama digunakan untuk melihat pengaruh variabel independen terhadap variabel intervening, yaitu Pendapatan $\left(\mathrm{X}_{1}\right)$, Beban $\left(\mathrm{X}_{2}\right)$ terhadap Laba Sebelum Pajak (Z). Tahap ini bertujuan untuk melihat pengaruh tidak langsung antara variabel independen terhadap variabel dependen melalui laba sebelum pajak sebagai variabel intervening. Persamaan regresi pada tahap pertama adalah sebagai berikut : $\mathrm{Z}=\mathrm{a}+\mathrm{b}_{1} \mathrm{X}_{1}+\mathrm{b}_{2} \mathrm{X}_{2 .}$

Pengujian dalam tahap pertama dilakukan dengan menguji seberapa besar kemampuan variabel pendapatan $\left(\mathrm{X}_{1}\right)$, dan Beban $\left(\mathrm{X}_{2}\right)$ dalam menjelaskan pengaruhnya terhadap variabel intervening, yaitu laba sebelum pajak (Z). Pengujian dilakukan dengan uji koefisien determinasi, ternyata berdasarkan hasil pengujian menunjukkan bahwa kemampuan variabel pendapatan dan beban dalam menjelaskan pengaruhnya terhadap variabel laba sebelum pajak adalah sebesar $88,3 \%$ dan mempunyai pengaruh tidak langsung sebesar $94,0 \%$ terhadap laba sebelum pajak.

Hasil pengujian secara simultan dengan uji ANOVA menujukkan hasil bahwa secara simultan variabel pendapatan dan beban berpengaruh positif dan signifikan terhadap laba sebelum pajak dengan nilai Fhitung sebesar 18,858 dengan tingkat signifikansi 0,005. Berdasarkan hasil uji secara simultan, ternyata variabel pendapatan dan beban merupakan variabel yang secara bersama-sama dapat berpengaruh terhadap laba sebelum pajak.

Hasil pengujian secara individual atau secara parsial dengan uji coeficientmenyatakan bahwa variabel pendapatan berpengaruh positif dan signifikan terhadap laba sebelum pajak dengan nilai thitung 4,760 dengan tingkat signifikansi sebesar 0,005 . Sedangkan beban memiliki pengaruh yang negatif dan signifikan terhadap laba sebelum pajak dengan nilai thitung $-2,567$ dengan tingkat signifikansi 0,050 . Pendapatan berpengaruh positif dan signifikan terhadap laba sebelum pajak, artinya semakin tinggi pendapatan yang diperoleh oleh PT. Bank Bengkulu, maka laba sebelum pajak juga akan meningkat dengan asumsi beban tidak mengalami peningkatan. Sedangkan semakin tinggi beban yang ditanggung oleh PT. Bank Bengkulu, maka laba sebelum pajak akan semakin menurun, karena beban dapat mengurangi nilai laba sebelum pajak.

\section{Uji Regresi Tahap Kedua}

Dalam uji regresi tahap kedua yaitu untuk melihat pengaruh antara variabel independen terhadap variabel dependen dengan laba sebelum pajak sebagai variabel intervening. Pengujian pada tahap ini bertujuan untuk melihat pengaruh langsung antara variabel indepeden terhadap variabel dependen. Persamaan regresi pada tahap pertama adalah sebagai berikut: $Y=a+b_{1} X_{1}+b_{2} X_{2}+b_{3} Z$.

Pengujian pada tahap ini sama hal nya pada tahap pertama, yaitu dengan menggunakan uji koefisien determinasi, uji anova dan uji secara individual. Hasil uji koefisien determinasi menujukkan bahwa variabel pendapatan dan beban mempu menjelaskan pengaruhnya terhadap pajak dengan laba sebelum pajak sebagai variabel intervening sebesar $96,1 \%$, sedangkan 3,9\% dijelaskan oleh variabel diluar penelitian. Artinya, pendapatan dan beban dengan laba sebelum pajak sebagai variabel intervening memiliki pengaruh yang besar terhadap pajak pada PT. Bank Bengkulu.

Hasil pengujian secara simultan atau uji ANOVA, menunjukkan bahwa variabel pendapatan dan beban dengan laba sebelum pajak sebagai variabel intervening mempunyai hubungan yang positif dan signifikan dengan nilai Fhitung 32,845 dengan tingkat signifikansi sebesar 0,003.

Hasil pengujian secara individual atau uji secara parsial menujukkan bahwa variabel pendapatan berpengaruh negatif dan tidak signifikan terhadap pajak dengan nilai thitung $-2,652$ dengan tingkat signifikansi sebesar 0,057 atau 5,7\%. Variabel beban berpengaruh positif dan signifikan terhadap pajak dengan nilai thitung 3,115 dengan tingkat signifikansi sebesar 0,036 atau 3,6\%. Sedangkan variabel laba sebelum pajak memiliki pengaruh yang positif dan signifikan terhadap pajak

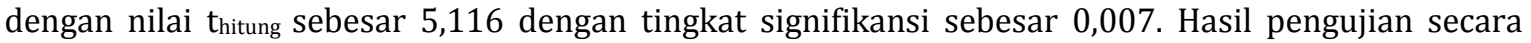
individual ini menunjukkan arah kekonsistenan terhadap teori dan analisa. Wajar jika pendapatan berpengaruh negatif terhadap pajak, karena semakin tinggi pendapatan yang diperoleh oleh PT. Bank Bengkulu, maka pihak PT. Bank Bengkulu juga akan membayar beban pajak yang besar. Arah pengaruh yang negatif antara pendapatan terhadap pajak dapat diterima dengan asumsi jika pendapatan semakin meningkat, maka semakin besar beban pajak yang ditanggung.

Variabel beban memiliki pengaruh yang positif dan signifikan terhadap pajak juga menujukkan arah yang konsisten, semakin besar beban operasional yang ditanggung oleh PT. Bank 
Bengkulu, maka akan semakin besar mengurangi nilai pendapatan dan akan berpengaruh terhadap laba sebelum pajak. Kecil nya perolehan laba kotor akan mengurangi beban pajak yang harus dibayar. Oleh sebab itu, benar jika beban berpengaruh positif dan signifikan terhadap pajak. Artinya, beban operasional mempunyai kontribusi yang besar terhadap beban pajak yang ditanggung.

Laba sebelum pajak juga menunjukan pengaruh yang positif dan signifikan terhadap pajak, hubungan yang positif dan signifikan ini menjelaskan bahwa semakin besar laba sebelum pajak maka akan semakin besar beban pajak yang ditanggung, sebaliknya jika semakin kecil laba sebelum pajak maka akan semakin kecil jumlah beban pajak yang ditanggung oleh PT. Bank Bengkulu.

\section{KESIMPULAN}

1. Pendapatan secara langsung berpengaruh negatif dan tidak signifikan terhadap pajak, dengan pengaruh total -1.400 dan tingkat signifikansi sebesar 0,057 atau $5,7 \%$. Sedangkan secara tidak langsung, pendapatan memiliki pengaruh yang positif dan signifikan terhadap pajak dengan pengaruh total sebesar 1.401 dan tingkat signifikansi sebesar 0,007 atau 0,07\%.Artinya, pendapatan tidak memiliki pengaruh langsung terhadap besarnya pajak PT. Bank Bengkulu, melainkan ada variabel lain yang mempengaruhi besarnya pajak PT. Bank Bengkulu yang dalam hal ini laba sebelum pajak sebagai variabel intervening memberikan kontribusi untuk mempengaruhi tingkat pajak. Karena variabel pendapatan memiliki pengaruh tidak langsung lebih besar dari pengaruh langsung, maka variabel laba sebelum pajak tepat digunakan sebagai variabel intervening.

2. Beban secara langsung memiliki pengaruh yang positif dan signifikan terhadap pajak sebesar 1.064 dengan tingkat signifikansi sebesar 0,036 atau 3,6\%. Sedangkan pengaruh tidak langsungnya sebesar 1.401 dengan tingkat signifikansi sebesar 0,007 attau $0,07 \%$. Beban baik secara langsung maupun tidak langsung dapat memberikan kontribusi terhadap pajak PT. Bank Bengkulu, besar atau kecilnya beban operasional dan beban non operasional akan berpengaruh terhadap pajak yang harus di bayar oleh PT. Bank Bengkulu. Semakin besar beban perusahaan, maka akan semakin kecil tingkat pajak yang bayar. Sebaliknya, semaking kecil beban perusahaan maka akan semakin besar tingkat pajak yang harus dibayar. Karena, beban perusahaan dapat memberikan pengaruh terhadap laba bersih sebelum pajak sebagai variabel intervening. Karena variabel beban memiliki pengaruh tidak langsung lebih besar dari pengaruh langsung, maka variabel laba sebelum pajak tepat digunakan sebagai variabel intervening.

\section{SARAN}

1. PT. Bank Bengkulu harus terus meningkatkan pendapatan dan menekan angka beban meskipun berpengaruh terhadap tingkat pembayaran pajak pengahasilan akan tetapi perusahaan harus terus berada dalam posisi yang menguntungkan.

2. Meskipun beban mempunyai pengaruh terhadap besarnya pajak yang dibayar, tetapi PT. Bank Bengkulu harus tetap menekan besarnya angka beban, karena besarnya beban akan mempengaruhi tingkat laba yang diperoleh oleh perusahaan.

\section{DAFTAR PUSTAKA}

Bernardin, Deden Edwar Yokeu. Baeti, Eva Nur. 2018. Laba Perushaan Sebagai Variabel Intervening Antara Pengaruh Biaya Operasional dan Volume Penjualan Terhadap Net Profit Margin, Studi Kasus Pada PT. Aero Globe Indonesia Tahun 2007-2014). Bandung : Universitas Bina Sarana Informatika. Jurnal.

Darminto, Dwi Prastowo. 2014. Analisis Laporan Keuangan, Konsep dan Aplikasi. Yogyakarta : UPP STIM YKPN.

Fahmi, Irham. 2015. Analisis Laporan Keuangan. Bandung : Alfabeta

Ghozali, Imam. 2011. Aplikasi Analisis Multivariat dengan Program SPSS, Edisi Ketiga. Jakarta : Badan Penerbit Universitas Diponegoro.

Hery. 2013. Akuntansi Keuangan Menengah. Yogyakarta : CAPS (Central of Academic Publishing Service).

........2016. Analisis Laporan Keuangan, Integrated and Comprehensive Edition. Jakarta : PT. Grasindo.

2017. Teori Akuntansi, Pendekatan Konsep dan Aplikasi. Jakarta : PT. Grasindo.

Ismail. 2010. Akuntansi Bank, Teori dan Aplikasi Dalam Rupiah, Edisi Revisi. Jakarta : Prenadamedia Group.

Jumingan. 2010. Analisis Laporan Keuangan. Jakarta : Bumi Aksara 
Kasmir .2014. Manajemen Perbankan, Edisi Revisi. Jakarta : PT. Raja Grapindo Persada.

Kasiram, Mohammad. 2008. Metode Penelitian Kualitatif-Kuantitatif. Malang : UIN Malang Press.

Munawir. 2011. Analisis Laporan Keuangan, Edisi Keempat. Yogyakarta : BPFE.

Nurjanah, Siti. 2008. Pengaruh Pendapatan dan Beban Terhadap Pajak : Laba Sebelum Pajak Sebagai Variabel Intervening, Studi Empiris Pada Perusahaan LQ45. Jakarta : Universitas Islam Syarif Hidayatullah. Skripsi. Tidak Dipublikasikan.

Resmi, Siti. 2008. Perpajakan Teori dan Kasus. Jakarta : Salemba Empat.

Riadi, Edi. 2016. Statistika Penelitian, Analisis Manual dan IBM SPSS. Yogyakarta : Andi.

Susena, Karona Cahya. Asriyani, Yennita. 2016. Faktor-Faktor Yang Mempengaruhi Kepatuhan Wajib Pajak Bumi dan Bangunan di Kecamatan Teluk Segara Kota Bengkulu. Jurnal : Fakultas Ekonomi Universitas Dehasen Bengkulu.

Sumarni, Murti. Soeprihanto, Jhon. 2014. Pengantar Bisnis (Dasar-Dasar Ekonomi Perusahaan). Edisi Ke Enam. Yogyakarta : Liberty.

Stice, K Earl. Fred, Skousen K. Abercht W Steve. Stice James D. 2009. Akuntansi Keuangan, Konsep dan Aplikasi, Edisi Kesembilan. Jakarta : Salemba Empat.

Wijaya, Tony. 2011. Cepat Menguasai SPSS 19. Yogyakarta : Cahaya Atma.

Yusuf, A. H. 2011. Dasar-Dasar Akuntansi, Jilid 2 Cetakan Pertama. Yogyakarta : STIE YKPN. 